\title{
Evidence for colorectal cancer cell specificity of aspirin effects on $\mathrm{NF} \kappa \mathrm{B}$ signalling and apoptosis
}

\author{
FVN Din', MG Dunlop*,I and LA Stark' \\ 'Colon Cancer Genetics Group, University of Edinburgh Department of Oncology and MRC Human Genetics Unit, Western General Hospital, Crewe Rd, \\ Edinburgh EH4 2XU, Scotland
}

\begin{abstract}
Epidemiological evidence indicates that non-steroidal anti-inflammatory drugs (NSAIDs) protect against colorectal cancer (CRC) to a greater degree than other non-gastrointestinal cancers, but the molecular basis for this difference is unknown. We previously reported that aspirin induces signal-specific $\mid \kappa \mathrm{B} \alpha$ degradation followed by $\mathrm{NF} \kappa \mathrm{B}$ nuclear translocation in $\mathrm{CRC}$ cells, and that this mechanism contributes substantially to aspirin-induced apoptosis. Here, we explored the hypothesis that cell-type specific effects on NF $\kappa \mathrm{B}$ signalling are responsible for the observed differences in protection by aspirin against CRC compared to breast and gynaecological cancers. We also assessed whether COX-2 expression, mutation status of adenomatous polyposis coli (APC), $\beta$-catenin, p53, or DNA mismatch repair (MMR) genes in CRC lines influenced aspirin-induced effects. We found that aspirin induced concentration-dependent $\mid \kappa \mathrm{B} \alpha$ degradation, $\mathrm{NF} \kappa \mathrm{B}$ nuclear translocation and apoptosis in all CRC lines studied. However, there was no such effect on the other cancer cell types, indicating a considerable degree of cell-type specificity. The lack of effect on NF $k$ B signalling, paralleled by absence of an apoptotic response to aspirin in non-CRC lines, strongly suggests a molecular rationale for the particular protective effect of NSAIDs against CRC. Effects on NF $\kappa$ B and apoptosis were observed irrespective of COX-2 expression, or mutation status in APC, $\beta$-catenin, p53 and DNA MMR genes, underscoring the generality of the aspirin effect on NF $\kappa$ B in CRC cells. These findings raise the possibility of cell-type specific targets for the development of novel chemopreventative agents.
\end{abstract}

British Journal of Cancer (2004) 91, 381-388. doi:I0.1038/sj.bjc.6601913 www.bjcancer.com

Published online 8 June 2004

(c) 2004 Cancer Research UK

Keywords: $\mid \kappa \mathrm{B} ; \mathrm{NF} \kappa \mathrm{B}$; NSAIDs; chemoprevention; colorectal cancer

Colorectal cancer (CRC) is common in developed countries (Parkin et al, 1999) and is a major contributor to cancer-related morbidity and mortality. Chemoprevention is an inherently appealing approach to combat the disease, and non-steroidal anti-inflammatory drugs (NSAIDs) have been associated with a substantial reduction in CRC incidence and mortality (Thun et al, 1993; Collet et al, 1999; Langman et al, 2000). Combined casecontrol data, including over 30000 CRC cases, indicate a $45 \%$ reduction in the risk of developing CRC in subjects taking NSAIDs. Although there is evidence for a protective effect of NSAIDs against non-gastrointestinal cancers, the data are less convincing and the risk reduction much less. In breast cancer, reports show conflicting results and a recent meta-analysis revealed a risk reduction of only $13 \%$ in case - control studies (Khuder and Mutgi, 2001), considerably lesser than that in CRC. Similarly, in endometrial and ovarian cancer, the available evidence suggests that NSAIDs confer little, if any, protection (Cramer et al, 1998; Rosenberg et al, 2000; Fairfield et al, 2002; Meier et al, 2002). Collectively, published data suggest that there is considerable heterogeneity of NSAID anti-tumour effect between cancer types. The particular protective effect against CRC suggests the

\footnotetext{
* Correspondence: Professor M Dunlop;

E-mail: Malcolm.Dunlop@hgu.mrc.ac.uk

Received 3 October 2003; revised 22 April 2004; accepted 23 April 2004; published online 8 June 2004
}

possibility that aspirin might target distinct molecular pathways in colonic epithelial cells. Elucidation of the molecular mechanism of this apparent differential sensitivity would lend further insight into both the mode of action of NSAIDs as well as identification of molecular markers of response.

The anti-tumour activity of NSAIDs has primarily been attributed to inhibition of the cyclooxygenase-2 enzyme (COX-2) and the resultant decrease in production of prostaglandins, as this remains the best-characterised effect (Vane, 1971). However, accumulating evidence from animal and cell culture experiments has shown that COX-2 inhibition is not the sole basis of NSAID anti-tumour activity (Alberts et al, 1995; Hanif et al, 1996; Elder et al, 1997; Piazza et al, 1997), suggesting that other targets are also involved. We previously reported that aspirin activates the $\mathrm{NF} \kappa \mathrm{B}$ signalling pathway and that this mechanism is of central importance to aspirin-mediated apoptosis in CRC cells (Stark et al, 2001). The NF $\kappa \mathrm{B}$ transcription factor is normally sequestered in the cytoplasm by an inhibitor protein, $\mathrm{I} \kappa \mathrm{B} \alpha$. Following stimulation of the $\mathrm{NF} \kappa \mathrm{B}$ pathway, $\mathrm{I} \kappa \mathrm{B} \alpha$ is phosphorylated, ubiquitinated and targeted for proteosomal degradation. Dissociation from $\mathrm{I} \kappa \mathrm{B} \alpha$ results in translocation of $\mathrm{NF} \kappa \mathrm{B}$ to the nucleus, where it contributes to the co-ordinated transcription of genes involved in inflammation, cell proliferation and apoptosis (Pahl, 1999). Our previous work demonstrated that aspirin induces timeand dose-dependent signal-specific degradation of $\mathrm{I} \kappa \mathrm{B} \alpha$, nuclear translocation of $\mathrm{NF} \kappa \mathrm{B}$ and apoptosis in CRC cells. Time-course experiments indicated that $\mathrm{I} \kappa \mathrm{B} \alpha$ degradation and $\mathrm{NF} \kappa \mathrm{B}$ nuclear 
translocation preceded cell death, suggesting a causal relationship. This was confirmed in cells we engineered to continuously express a dominant-negative mutant $\mathrm{I} \kappa \mathrm{B} \alpha(\mathrm{I} \kappa \mathrm{B} \alpha \mathrm{S} 32 / 36)$, which showed inhibition of both aspirin-induced $\mathrm{NF} \kappa \mathrm{B}$ nuclear translocation and apoptosis compared to their parental counterparts (Stark et al, 2001). This work alluded to the notion of specificity since the $\mathrm{NF} \kappa \mathrm{B}$ response was not observed in the control cell lines $293 \mathrm{HEK}$ and A549, which were non-colorectal in origin.

Here, we focus on the important issue of the specificity of aspirin's protective effects, as observed in epidemiological studies, and we set out to determine whether cell-type specific effects on the $\mathrm{NF} \kappa \mathrm{B}$ signalling pathway reflect the differential protective effects of aspirin in different cancer types. In particular, we wished to determine whether the lower protective effect observed for breast, ovarian and endometrial cancer can be explained by differing effects on the $\mathrm{NF} \kappa \mathrm{B}$ signalling pathway. We also investigated the generality of the $\mathrm{NF} \kappa \mathrm{B}$ response to aspirin in CRC by studying a panel of CRC cell lines with different genetic defects common in bowel malignancy. Here, we present evidence showing clear differences in $\mathrm{NF} \kappa \mathrm{B}$ response that parallel the epidemiological data, supporting the notion that the ability of aspirin to modulate the $\mathrm{NF} \kappa \mathrm{B}$ signalling pathway is a key determinant of the anti-tumour effect and that this is cell-type specific. Our findings provide further insight into the complex mechanisms by which NSAIDs exert an anti-tumour effect in CRC cells, and raise the possibility of cell-type specific molecular targets in CRC.

\section{MATERIALS AND METHODS}

\section{Cell line culture and treatment}

The CRC cell lines used were HRT-18, SW480, HT-29, DLD-1, LoVo and HCT116; breast cancer lines were T47-D, MCF-7 and MDA-MB-231; ovarian cancer line was A2780 and endometrial cancer line was HEC-1-A. All cancer cell lines are available from the American Type Culture Collection. The mutation status for the adenomatous polyposis coli (APC), p53, $\beta$-catenin and DNA mismatch repair (MMR) genes of the cell lines studied is shown in Table 1. Cell lines were grown as monolayers $\left(37^{\circ} \mathrm{C}\right.$ in $\left.5 \% \mathrm{CO}_{2}\right)$ in RPMI (HRT-18, DLD-1 and A2780), DMEM (HT-29, T47-D, MCF7, MDA-MB-231, HEC-1-A), L-15 (SW480) and McCoy's 5A media (HCT116) supplemented with $10 \%$ foetal calf serum (FCS) and $1 \%$ penicillin/streptomycin (media supplied by Gibco BRL, Paisley, UK). Cells were plated $\left(1 \times 10^{6}\right.$ cells $/ 50 \mathrm{ml}$ flask $)$ and grown until $60-70 \%$ confluent, prior to treatment with aspirin or carrier control at the same concentrations as the aspirin treatment. Aspirin (Sigma, St Louis, USA) was prepared as a $0.5 \mathrm{~m}$ stock solution in distilled water (final $\mathrm{pH} 7.0$ ). Growth medium was replaced with the respective low serum $(0.5 \%$ FCS $)$ medium and cells were treated with aspirin at 1, 3, 5 and $10 \mathrm{~mm}$ for $24 \mathrm{~h}$ (or $72 \mathrm{~h}$ ), or with carrier as a control.

\section{Cell viability and determination of apoptosis}

Adherent cells were harvested and viable cell number determined by haemocytometric counts with nigrosin exclusion. $\mathrm{IC}_{50}$ values for the CRC cell lines were calculated using the XLfit $3^{\mathrm{TM}}$ software. Apoptosis was detected via its interaction with annexin $\mathrm{V}$ using an Annexin V-FITC apoptosis detection kit (Oncogene Research Products, Cambridge, MA, USA), as per the manufacturer's instructions. Briefly, the medium from the flask of adherent cells was transferred to a conical tube on ice to harvest any floating cells. Cells were then washed with $2 \mathrm{ml}$ of PBS, which was also added to the tube to collect any cells dislodged during washing. Cells were incubated with $1 \mathrm{ml}$ of trypsin:versene (volume per volume) just until the cells detached and then resuspended in the
Table I Mutation status of cancer cell lines studied

\begin{tabular}{lllll}
\hline Cell line & APC & $\boldsymbol{\beta}$-catenin & p53 & MMR \\
\hline HRT-18 & Mutant & Wild type & Mutant & Deficient \\
SW480 & Mutant & Wild type & Mutant & Proficient \\
HT-29 & Mutant & Wild type & Mutant & Proficient \\
DLD-I & Mutant & Wild type & Mutant & Deficient \\
LoVo & Mutant & Wild type & Wild type & Deficient \\
HCT-I I6 & Wild type & Mutant & Wild type & Deficient \\
MCF-7 & Wild type & Wild type & Wild type & Proficient \\
MDA-MB23I & Wild type & Wild type & Mutant & Not known \\
T47D & Wild type & Wild type & Mutant & Proficient \\
A2780 & Wild type & Wild type & Wild type & Proficient \\
HEC-I-A & Not known & Not known & Not known & Deficient \\
\hline
\end{tabular}

conical tube containing the media with the floating and washed cells. Cells were counted using a haemocytometer and resuspended in cold $1 \times$ binding buffer to approximately $1 \times 10^{6} \mathrm{cells} \mathrm{ml}^{-1}$. Media-binding reagent $(10 \mu \mathrm{l})$ was added to $0.5 \mathrm{ml}$ of the cell suspension, which was incubated with $1.25 \mu \mathrm{l}$ of annexin V-FITC for $15 \mathrm{~min}$ at room temperature in the dark. Annexin $\mathrm{V}$ was then removed by centrifugation at $1000 \mathrm{~g}$ for $5 \mathrm{~min}$ and the cells were resuspended in $0.5 \mathrm{ml}$ of cold $1 \times$ binding buffer and placed on ice. The counting was done using a haemocytometer (two counting grids) in duplicate and this was carried out immediately following staining of cells, as apoptosis is an ongoing process and the FITC signal may be lost after an hour.

\section{Western blotting}

Cells were washed with PBS, centrifuged (1200 r.p.m., $10 \mathrm{~min}$ ) and cell pellets resuspended in lysis buffer $(50 \mathrm{~mm} \mathrm{NaCl}, 10 \mathrm{~mm}$ HEPES, $500 \mathrm{~mm}$ sucrose, $1 \mathrm{~mm}$ EDTA, $0.5 \mathrm{~mm}$ spermidine, $0.15 \mathrm{~mm}$ spermine, $0.2 \%$ Triton X-100) containing complete Protease Inhibitor Cocktail and $100 \mathrm{~mm}$ Pefabloc (Roche Diagnostics, Manheim, Germany). The cell suspension was centrifuged (6000 r.p.m., $15 \mathrm{~min}, 4^{\circ} \mathrm{C}$ ) and the supernatant containing cytoplasmic proteins aliquoted. Protein content was measured by the method of Bradford (BioRad, Hercules, California, USA). Cytoplasmic proteins $(30 \mu \mathrm{g})$ were separated on a $10 \%$ SDS-PAGE gel, transferred to a polyvinylidine difluoride membrane (BioRad) and blocked in $4 \%$ non-fat dry milk solution with $0.3 \%$ Tween 20 (Sigma). Membranes were probed with a sheep polyclonal $\mathrm{I} \kappa \mathrm{B} \alpha$ antibody (a gift from Professor R Hay, University of St Andrews, UK), rabbit polyclonal p65 antibody (Santa Cruz, California, USA) or mouse monoclonal COX-2 antibody (Cayman Chemicals, Michigan, USA). COX-2 electrophoresis standard (Cayman Chemicals) was used to indicate the correct COX-2 band. Monoclonal antibody to $\mathrm{Cu} / \mathrm{Zn}$ SOD (The Binding Site, Birmingham, UK) and to actin (Santa Cruz) was used as a control for protein loading. Antigen - antibody complexes were visualised with chemiluminescence (Amersham ECL Reagents, UK).

\section{Immunofluorescence analysis}

Cells grown to $60-70 \%$ confluence on glass coverslips were treated with carrier or $10 \mathrm{~mm}$ aspirin for $24 \mathrm{~h}$ (in the respective $0.5 \%$ FCS medium). After treatment, cells were washed with PBS, fixed with acetone:methanol (volume per volume $)\left(-20^{\circ} \mathrm{C}, 10 \mathrm{~min}\right)$ and blocked in $10 \%$ pre-immune donkey serum (Sigma) for $1 \mathrm{~h}$. Rabbit polyclonal antibody to NF $\kappa$ B p65 (Santa Cruz) was applied for $1 \mathrm{~h}$, followed by incubation with FITC-conjugated donkey anti-rabbit IgG for $1 \mathrm{~h}$. The nuclei were stained with DAPI and the coverslips mounted with Vectashield (Vector Laboratories, Burlingame, California, USA). 


\section{RESULTS}

\section{Colorectal cancer cells are more susceptible to aspirin- induced apoptosis than non-CRC cells}

We studied the effect of aspirin on the growth of a panel of CRC cell lines (HRT-18, SW480, HT-29, DLD-1, LoVo and HCT116) in comparison to cell lines derived from other cancer types: breast (MCF-7, MDA-MB-231, T47D), ovarian (A2780) and endometrial (HEC-1-A). The non-CRC cell lines were chosen based on epidemiological data, where there is some evidence to suggest a protective effect in breast cancer and less so in ovarian and endometrial cancer.

In triplicate dose-response experiments, cell lines were treated for $24 \mathrm{~h}$ with aspirin at concentrations of $1,3,5$ and $10 \mathrm{~mm}$, and viable cell number determined by haemocytometric counts. We found a concentration-dependent decrease in viable cell number in each of the six CRC cell lines studied (Figure 1A). In contrast, there was no demonstrable effect of aspirin on the viability of the nonCRC cell lines MCF-7, MDA-MB-231, A2780 and HEC-1-A (Figure 1A). Interestingly, the T47D breast cancer cells did exhibit a dose-dependent reduction in viability, although this effect was not so pronounced as that seen in CRC cells at low aspirin concentrations. The $\mathrm{IC}_{50}$ values were calculated from the growth curves of the aspirin-treated CRC cell lines only, as there was no consistent reduction in cell viability in the non-CRC cell lines (Table 2). The mean $\mathrm{IC}_{50}$ value for the CRC cell lines was $2.38 \mathrm{~mm}$ and the greatest incremental reduction in viability in these cells was observed between 0 and $1 \mathrm{~mm}$ concentrations, which is comparable to serum concentrations attainable in humans (Pachman et al, 1979).

We next wished to establish whether the reduction in viable cell number that we observed in the CRC cell lines was due to induction of apoptosis. Annexin- $\mathrm{V}$ binding of phosphatidylserine residues externalised during apoptosis was used to determine the proportion of cells undergoing programmed cell death in response to increasing concentrations of aspirin. We found that aspirin treatment induced a concentration-dependent increase in apoptosis in all six of the CRC cell lines studied, confirming that induction of apoptosis is responsible for the observed reduction in cell viability (Figure 1B). There was no dose-dependent increase in apoptosis in the non-CRC cell lines following aspirin treatment, which was consistent with the lack of effect on cell viability (Figure 1A). Although the T47D breast cancer cells did exhibit a reduction in viable cell count, this effect was less marked than that seen in CRC cells and, furthermore, there was no increase in apoptosis in this cell line. To confirm that the non-CRC cells were less sensitive to apoptosis, we treated three non-CRC cell lines (two breast and one ovarian) and one CRC cell line (SW480) with aspirin for a longer time period of $72 \mathrm{~h}$. Indeed, the non-CRC cell lines were far less susceptible to apoptosis compared to the CRC cell line despite treatment with aspirin for $72 \mathrm{~h}$ (Figure $1 \mathrm{C}$ ). These findings demonstrate that the anti-tumour activity of aspirin has a substantial degree of specificity for CRC cells in vitro, reflecting the epidemiological evidence for a greater protective effect against $\mathrm{CRC}$ compared to other cancer types.

We also considered whether defects in genes commonly mutated in CRC, and known to affect apoptotic pathways, might influence such cell death. Mutation status for APC, $\beta$-catenin, p53 and DNA MMR genes (Table 1) does not appear to influence aspirin-induced apoptosis in CRC lines, emphasising the relevance of the aspirin $\mathrm{NF} \kappa \mathrm{B}$ anti-tumour effect to CRC in general.

Differential sensitivity to the apoptotic effects of aspirin is paralleled by differing responses of the NF $\kappa \mathrm{B}$ pathway

Our previous work indicates that $\mathrm{NF} \kappa \mathrm{B}$ nuclear translocation is a key component of aspirin-induced apoptosis in CRC cells. We therefore considered whether the variations in cell viability, observed between CRC and non-CRC cell lines, were attributable to differing responses of the $\mathrm{NF} \kappa \mathrm{B}$ pathway to aspirin. We first investigated the effect of aspirin on cytoplasmic levels of the $\mathrm{NF} \kappa \mathrm{B}$ inhibitor protein $\mathrm{I} \kappa \mathrm{B} \alpha$, using immunoblot analysis. We found that aspirin treatment resulted in concentration-dependent degradation of $\mathrm{I} \kappa \mathrm{B} \alpha$, as indicated by a reduction in cytoplasmic $\mathrm{I} \kappa \mathrm{B} \alpha$ protein levels (Figure 2A) in all CRC cell lines. Although the $\mathrm{I} \kappa \mathrm{B} \alpha$ degradation may be more obvious at the higher doses, there is degradation at the lower doses of 1 and $3 \mathrm{~mm}$ aspirin (Figure 2A). The $\mathrm{IC}_{50}$ values for the CRC cell lines range from 1.48 to $3.12 \mathrm{~mm}$ aspirin, demonstrating differential sensitivity to aspirin with respect to the concentration at which $50 \%$ of the cells are growth inhibited (Table 2). The SW480 and HT-29 cell lines have IC $_{50}$ values at the lower end of the range $(1.48$ and $1.98 \mathrm{~mm}$, respectively) and do undergo $\mathrm{I} \kappa \mathrm{B} \alpha$ degradation at $1 \mathrm{~mm}$, whereas the HRT-18 and DLD-1 cell lines have $\mathrm{IC}_{50}$ values of 3.12 and $2.92 \mathrm{~mm}$ and also exhibit $\mathrm{I} \kappa \mathrm{B} \alpha$ degradation at $3 \mathrm{~mm}$. Hence, there is a close relationship between $\mathrm{IC}_{50}$ values and $\mathrm{I} \kappa \mathrm{B} \alpha$ degradation for the individual CRC cell lines. In striking contrast, there was no change in $\mathrm{I} \kappa \mathrm{B} \alpha$ levels upon aspirin treatment in any of the non$\mathrm{CRC}$ cell lines even at the highest dose of $10 \mathrm{~mm}$ (Figure 2B).

Since these findings suggested a cell-type specific $\mathrm{NF} \kappa \mathrm{B}$ response to aspirin, we next determined whether the disparate $\mathrm{I} \kappa \mathrm{B} \alpha$ response was accompanied by a differential effect on $\mathrm{NF} \kappa \mathrm{B}$ nuclear translocation in the CRC compared to the non-CRC cell lines. Immunofluorescence analysis showed that p65, the transcriptionally active subunit of $\mathrm{NF} \kappa \mathrm{B}$, was primarily located in the cytoplasm in untreated cells as expected (Figure 2C, D, first panel). Following aspirin treatment, there was nuclear accumulation of p65 in all of the CRC cells (Figure 2C, second panel). However, in keeping with our observation that there was no $\mathrm{I} \kappa \mathrm{B} \alpha$ degradation in the non-CRC cells, aspirin treatment did not induce nuclear translocation of p65 in any of these cell lines (Figure 2D, second panel). These data establish that the disparity in viability following exposure to aspirin in CRC lines compared to lines derived from other cancer types is associated with markedly differing responses of the $\mathrm{NF} \kappa \mathrm{B}$ pathway to aspirin. This work suggests that the effect of aspirin on $\mathrm{NF} \kappa \mathrm{B}$ signalling may be implicated in the differential sensitivity of cancer types to aspirin-induced apoptosis.

\section{Basal $I \kappa B \alpha$ and p65 protein levels and aspirin-induced apoptosis in CRC cell lines}

High basal $\mathrm{NF} \kappa \mathrm{B}$ activity and aberrant $\mathrm{I} \kappa \mathrm{B} \alpha$ expression have been observed in a number of cancers including CRC (Rayet and Gelinas, 1999). In view of our findings of a cell-type specific NF $\kappa \mathrm{B}$ and death response to aspirin, we considered whether the basal levels of $\mathrm{I} \kappa \mathrm{B} \alpha$ and p65 might determine increased sensitivity to apoptosis, and so could be potential molecular markers of response. We used immunoblot analysis of cytoplasmic extracts to examine basal levels of $\mathrm{I} \kappa \mathrm{B} \alpha$ and p65 in both the CRC and nonCRC cell lines (Figure 3). There was no difference in expression of $\mathrm{I} \kappa \mathrm{B} \alpha$ or $\mathrm{p} 65$ or their relative levels (analysed by densitometry, data not shown) between colorectal and non-CRC cells that could account for increased sensitivity to apoptosis. These results indicate that sensitivity to aspirin-induced apoptosis is not related to the cytoplasmic pool of either protein available for stimulation.

\section{Basal COX-2 protein levels do not determine the NF $\boldsymbol{B} B$ response to aspirin}

Increased COX-2 expression has been observed both in premalignant colonic lesions and CRCs (Eberhart et al, 1994), and COX-2 inhibition has been shown to play a role in aspirin-mediated cell death (Boolbol et al, 1996). Hence, we considered whether COX-2 expression might explain the heterogeneity of the aspirin response between the CRC and non-CRC cell lines. Immunoblot analysis of 
cytoplasmic proteins demonstrated considerable variation in basal levels of COX-2 between the CRC cell lines (Figure 4). The CRC cell lines SW480 and HCT116 do not express COX-2, whereas HT-29 and LoVo do express COX-2, and yet all underwent apoptosis following aspirin treatment. In the non-CRC panel, the MCF-7 cell line does not express COX-2 but the MDA-MB-231 cell line does

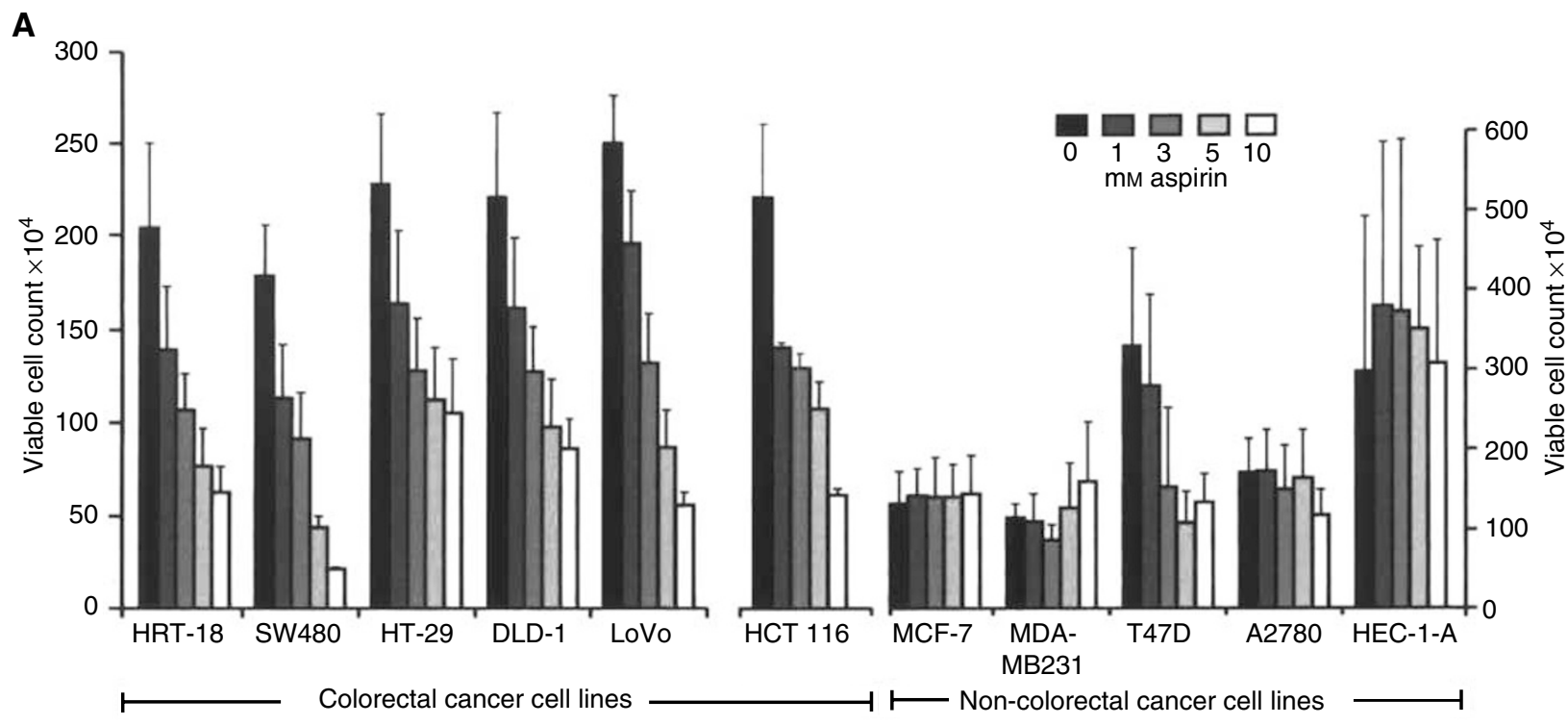

B

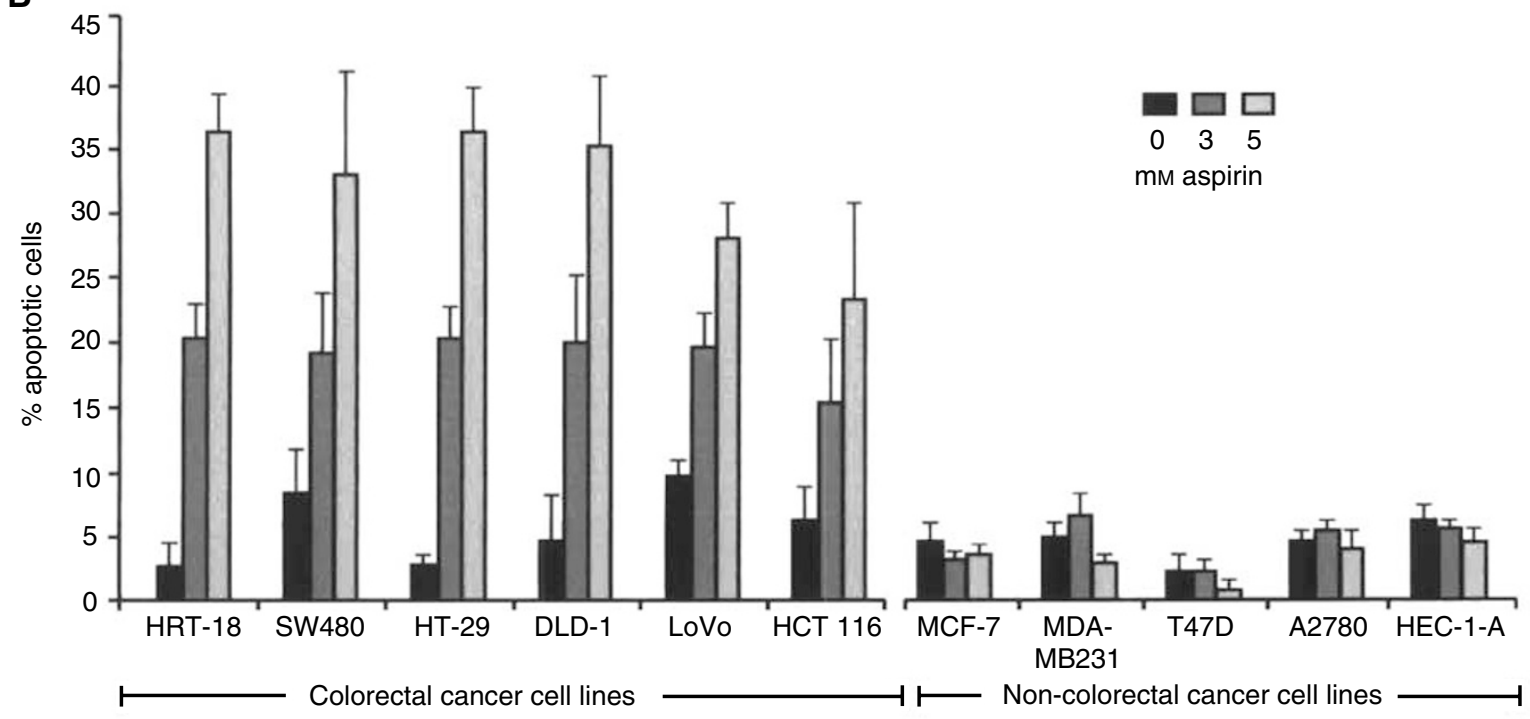

C
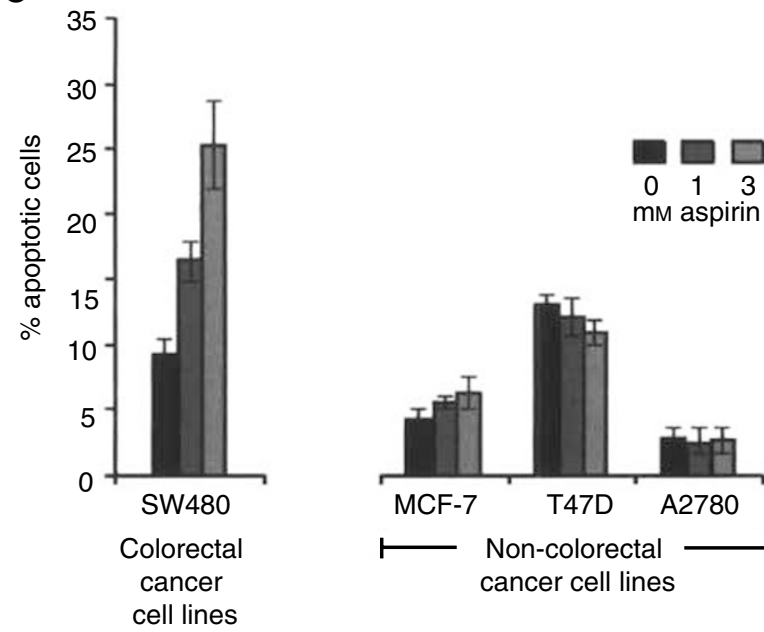

$\mathrm{mm}$ aspirin

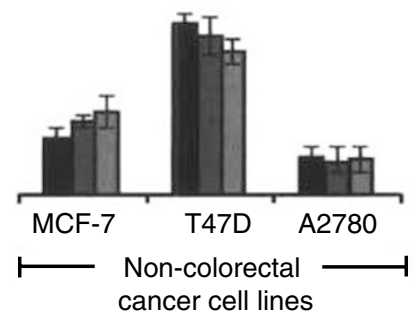


Table $2 \quad I C_{50}$ values for colorectal cancer cell lines

\begin{tabular}{lc}
\hline Cell line & IC $_{\mathbf{5 0}}$ \\
\hline HRT-18 & $3.12 \pm 0.69$ \\
SW480 & $1.48 \pm 0.12$ \\
HT-29 & $1.98 \pm 0.68$ \\
DLD-I & $2.92 \pm 0.58$ \\
LoVo & $2.07 \pm 0.25$ \\
HCT-II6 & $2.71 \pm 0.46$ \\
\hline
\end{tabular}

express COX-2, but neither undergoes aspirin-induced apoptosis. Similarly, there was variability of COX-2 levels between the CRC lines and the non-CRC lines (Figure 4). Thus, we found no association between basal levels of COX-2 expression and sensitivity to aspirin-induced apoptosis, providing further support for the notion that COX-independent mechanisms play an important role in the anti-tumour effect of NSAIDs.

\section{DISCUSSION}

The work presented here demonstrates a striking difference in the response to aspirin between CRC cell lines and lines derived from other cancer types, with respect to both cell viability and $\mathrm{NF} \kappa \mathrm{B}$ signalling. We show that aspirin-induced apoptosis, associated with $\mathrm{I} \kappa \mathrm{B} \alpha$ degradation and $\mathrm{NF} \kappa \mathrm{B}$ nuclear translocation, was restricted to CRC cells. This relationship between aspirin-induced apoptosis and the effect on $\mathrm{NF} \kappa \mathrm{B}$ signalling suggests a molecular rationale for the particular sensitivity of CRC to NSAIDs compared to other cancers. These findings also extend our previous observations on the importance of the $\mathrm{NF} \kappa \mathrm{B}$ pathway as a key NSAID target.

Epidemiological evidence indicates that NSAIDs impart greater protection against CRC than other cancer types, but the molecular basis for this effect is not known. Several previous reports, including our own, have shown that aspirin induces apoptosis in CRC cells (Hanif et al, 1996; Elder et al, 1997; Piazza et al, 1997; Qiao et al, 1998; Castano et al, 1999; Stark et al, 2001). There is little data directly comparing the anti-tumour effects of NSAIDs in vitro between CRC cells and cancer cells of different tissue origin. A recent study has demonstrated a tissue type-independent effect in prostate, lung, colon, tongue and pancreatic cancer using nitric oxide-donating NSAIDs and, although treatment with conventional NSAIDs did have a growth-inhibitory effect, it was observed at concentrations in excess of the pharmacologically relevant range after $48 \mathrm{~h}$ of treatment (Kashfi et al, 2002). Our findings demonstrate that aspirin has a considerable degree of specificity of apoptotic effect for CRC cells compared to other cell lines studied, and this reflects the epidemiological observations in the respective tumours. We show that aspirin induces apoptosis in a panel of CRC cell lines, but has no consistent effect on viability and apoptosis in cancer cell lines of non-colorectal origin. These results contrast with some previous reports of NSAID-induced growth inhibition and apoptosis in breast and endometrial cancer cells (Noguchi et al, 1995; Planchon et al, 1995; Han et al, 1998; Arango et al, 2001), but these differences are reconciled by considering that these studies used NSAIDs other than aspirin (Noguchi et al,
1995; Planchon et al, 1995; Han et al, 1998), while others only observed apoptosis after long exposures $(48-96 \mathrm{~h})$ to high concentrations of salicylate out with the therapeutic range (Sotiriou et al, 1999; Arango et al, 2001). The non-CRC cell lines are susceptible to other apoptosis-inducing agents and $\mathrm{NF} \kappa \mathrm{B}$ activators such as staurosporine and $\mathrm{TNF} \alpha$, respectively, indicating that these cell lines are not generally resistant to apoptosis or $\mathrm{NF} \kappa \mathrm{B}$ modulation (Mooney et al, 2002; Tang et al, 2002). The observation that aspirin decreased cell viability in one of the three breast cancer cell lines (T47D) is in keeping with epidemiological data that suggest a lesser protective effect of NSAIDs against breast cancer. One cohort epidemiological study showed that the effect of aspirin use on CRC incidence was reduced in females (Schreinemachers and Everson, 1994), raising the possibility that differential protection may be related to gender. However, gender is unlikely to impart a predominant protective effect, as it has not been borne out by subsequent studies (Thun et al, 1993). Indeed, the HT-29 CRC cell line is derived from a female patient and is equally susceptible to aspirin-mediated apoptosis and $\mathrm{NF} \kappa \mathrm{B}$ modulation as the other CRC cell lines, which are male in origin. Our findings clearly indicate important differences between CRC and other cancer types with respect to aspirin effects on cell viability and apoptosis.

We show that aspirin-induced apoptosis occurs following $\mathrm{I} \kappa \mathrm{B} \alpha$ degradation and $\mathrm{NF} \kappa \mathrm{B}$ nuclear translocation, and that this effect is common to all CRC cell lines studied. Notably, this effect on the $\mathrm{NF} \kappa \mathrm{B}$ pathway was consistent between CRC cell lines despite heterogeneity of the lines, with respect to the profile of mutations in APC, $\beta$-catenin, p53 and DNA MMR genes (see Table 1). In contrast, aspirin treatment did not induce $\mathrm{I} \kappa \mathrm{B} \alpha$ degradation or $\mathrm{NF} \kappa \mathrm{B}$ nuclear translocation in any cell lines derived from cancers of other tissue types, paralleling the lack of consistent changes in cell viability and apoptosis in these lines. We have previously established that the observed effect of aspirin on $\mathrm{I} \kappa \mathrm{B} \alpha$ and $\mathrm{p} 65$ is a cause of rather than a consequence of apoptosis, based on the findings that the $\mathrm{I} \kappa \mathrm{B} \alpha$ degradation was signal-specific and that nuclear translocation of $\mathrm{NF} \kappa \mathrm{B}$ and apoptosis were blocked by a dominant-negative super repressor $\mathrm{I} \kappa \mathrm{B} \alpha$ (Stark et al, 2001). Furthermore, we showed that $\mathrm{I} \kappa \mathrm{B}$ degradation and $\mathrm{NF} \kappa \mathrm{B}$ nuclear translocation occur at $2-5 \mathrm{~h}$ after aspirin treatment and persists thereafter to $24 \mathrm{~h}$, whereas apoptosis is not observed to increase until at least $16 \mathrm{~h}$ and continues to $24 \mathrm{~h}$. Hence, the weight of evidence presented here correlating $\mathrm{I} \kappa \mathrm{B} \alpha$ degradation and $\mathrm{p} 65$ nuclear translocation with apoptosis compared to the lack of response in non-CRC cell lines provides considerable further support for a causal role of the $\mathrm{NF} \kappa \mathrm{B}$ response as an important component of aspirin-induced apoptosis.

Having shown a striking difference between the CRC and nonCRC cell lines, with respect to aspirin effects on $\mathrm{NF} \kappa \mathrm{B}$ signalling and apoptosis, we investigated potential factors that might contribute to the ability of specific cell types to undergo apoptosis. Increased $\mathrm{NF} \kappa \mathrm{B}$ activity has been observed in CRC (Hardwick et al, 2001) and relative resistance to apoptosis has been attributed to high constitutive $\mathrm{NF} \kappa \mathrm{B}$ activity in other cancers (Bours et al, 1994; Lind et al, 2001; Charalambous et al, 2003). However, we found no evidence that the specificity of the aspirin-NF $\kappa \mathrm{B}$ response is related to differential expression of basal $\mathrm{I} \kappa \mathrm{B} \alpha$ or p 65 proteins or their relative expression. The SW480 and HT-29 CRC cell lines undergo $\mathrm{NF} \kappa \mathrm{B}$-mediated apoptosis, despite the considerable

Figure I Differential effect of aspirin on cell viability and apoptosis in CRC and non-CRC cell lines. Aspirin treatment $(0-10 \mathrm{~mm})$ for $24 \mathrm{~h}$ induces a concentration-dependent decrease in viable cell number (determined by haemocytometric counts) in all CRC cell lines, but there is no consistent change in the non-colorectal cancer cell lines $(\mathbf{A})$. Annexin $\vee$ binding assay is used to determine whether all $C R C$ cell lines undergo apoptosis after aspirin treatment $(0-5 \mathrm{~mm})$ for $24 \mathrm{~h}$, but there was no change in apoptosis in the non-CRC cell lines $(\mathbf{B})$. Annexin $\mathrm{V}$ binding assay is used to determine whether the non-CRC cell lines are less susceptible to aspirin-induced apoptosis compared to the CRC cell line SW480 following treatment for $72 \mathrm{~h}$ with aspirin $(0-3 \mathrm{mM})(\mathbf{C})$. The graphs represent three independent experiments and the bars on the graphs are standard error bars. 


\section{A}

HRT-18

$\mathrm{I}_{\kappa} \mathrm{B} \alpha-\cdots$

$\mathrm{Cu} / \mathrm{ZnSOD}=--\cdots$

HT29

DLD-1

$\mathrm{I} \mathrm{B} \alpha-\cdots$

$\mathrm{Cu} / \mathrm{ZnSOD}$

$\mathrm{I} \kappa \mathrm{B} \alpha=-\cdots$

$\mathrm{Cu} / \mathrm{ZnSOD}$

$\mathrm{I}_{\kappa} \mathrm{B} \alpha-\ldots$

$\mathrm{Cu} / \mathrm{ZnSOD}$

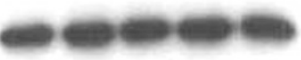

HCT 116

$\mathrm{I} \kappa \mathrm{B} \alpha--\infty-2$

$\mathrm{Cu} / \mathrm{ZnSOD}$

$\begin{array}{lllll}0 & 1 & 3 & 5 & 10\end{array}$ $\mathrm{mm}$ aspirin

B

MCF-7
$\mathrm{I} \kappa \mathrm{B} \alpha$

$\mathrm{Cu} / \mathrm{ZnSOD}$

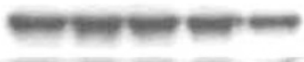

$\mid \kappa \mathrm{B} \alpha$

$\mathrm{Cu} / \mathrm{ZnSOD}$

$\kappa \mathrm{B} \alpha$

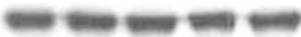

$\mathrm{Cu} / \mathrm{ZnSOD}$

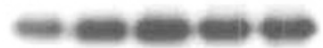

T47D

A2780

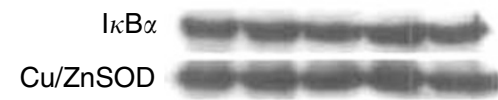

HEC-1-A

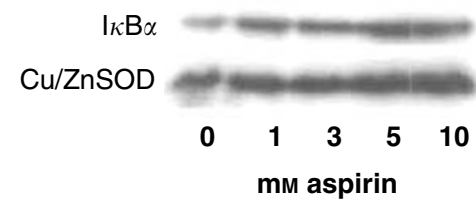

C

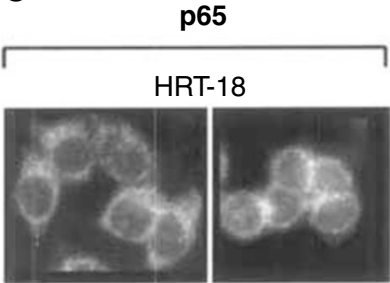

SW480



LoVo

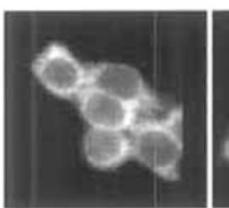

Untreated

$10 \mathrm{~mm}$

aspirin

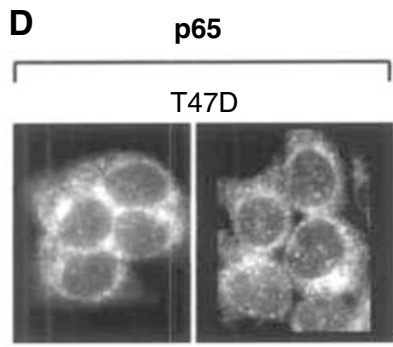

A2780

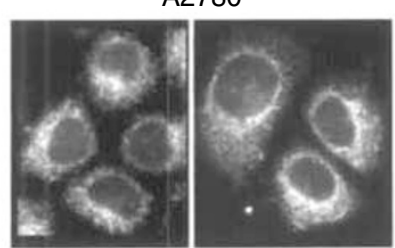

HEC -1-A

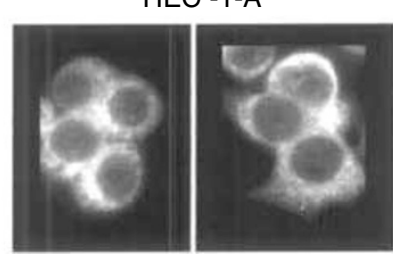

Untreated

$10 \mathrm{~mm}$

aspirin

Figure 2 Aspirin-induced $\mid \kappa B \alpha$ degradation and p65 nuclear translocation is restricted to CRC lines. Western blot analysis shows that aspirin treatment $(0-10 \mathrm{~mm})$ for $24 \mathrm{~h}$ induces $\mid \kappa \mathrm{B} \alpha$ degradation in a concentration-dependent manner in the CRC cell lines $(\mathbf{A})$, but not in the non-CRC cell lines $(\mathbf{B})$ Following aspirin treatment, cytoplasmic extracts were made from untreated and treated cells and probed with sheep polyclonal I $\kappa \boldsymbol{B} \alpha$ antibody. The western blot shown is representative of at least three independent experiments, and $\mathrm{Cu} / \mathrm{Zn} \mathrm{SOD}$ was used as a control for protein loading. Micrographs ( $\times$ 63) of immunocytochemically stained cells show that aspirin treatment $(10 \mathrm{~mm})$ for $24 \mathrm{~h}$ induces nuclear accumulation of p65 in the CRC cell lines (C), but not in the non-CRC cell lines (D). 


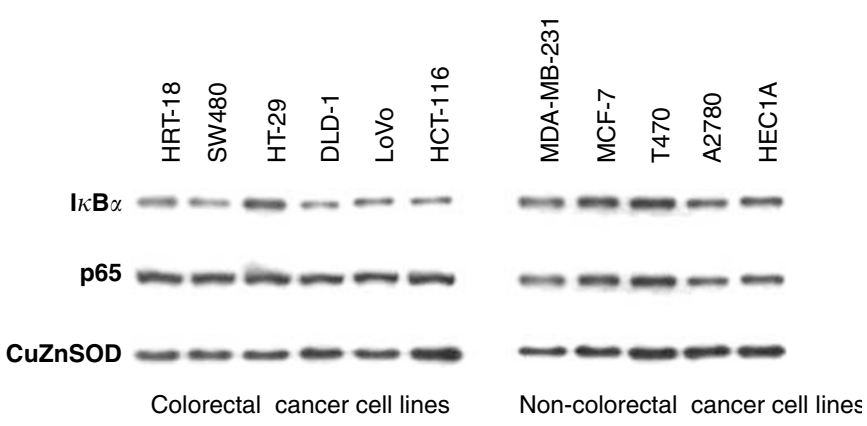

Figure 3 Western blot analysis demonstrates basal expression levels of cytoplasmic $\mid \kappa \mathrm{B} \alpha$ and p65 proteins in CRC and non-CRC cell lines in untreated cells. Cytoplasmic extracts were made from untreated cells and probed with sheep polyclonal $\mid \kappa \mathrm{B} \alpha$ antibody and rabbit polyclonal p65 antibody. The western blot shown is representative of at least three independent experiments and $\mathrm{Cu} / \mathrm{Zn} \mathrm{SOD}$ was used as a control for protein loading.

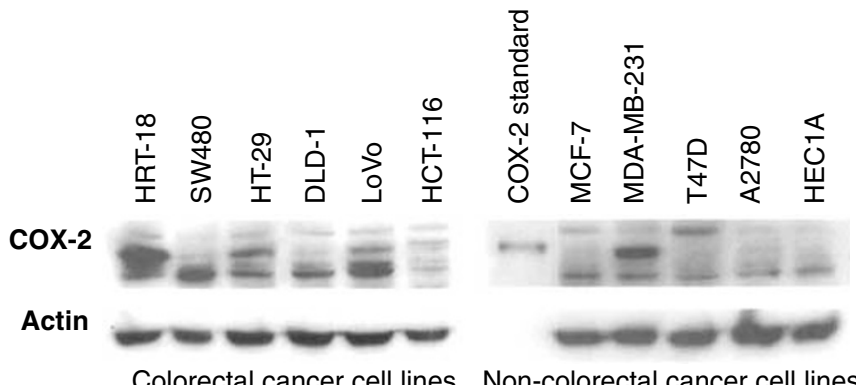

Figure 4 Western blot analysis of basal expression levels of cytoplasmic COX-2 protein in CRC and non-CRC cell lines. Cytoplasmic extracts were made from untreated cells and probed with mouse monoclonal COX-2 antibody. A COX-2 electrophoresis standard ( $72 \mathrm{kDa}$ monomer) is used to indicate the COX-2 band. COX-2 is expressed in the HRT-18, HT-29, LoVo and MDA-MB-23I cell lines. The Western blot shown is representative of at least three independent experiments and actin was used as a control for protein loading.

difference in basal $\mathrm{NF} \kappa \mathrm{B}$ activity previously reported between these cell lines (Dejardin et al, 1999).

There is substantial rationale for investigating COX-2 as a potential molecular determinant of response, in view of its role in CRC development and as a pharmacological target for NSAIDs. Additionally, it has been reported that the inconclusive nature of epidemiological data in breast cancer might be related to the observation that only a subset of breast cancers express COX-2 (Howe et al, 2001). In the work presented here, we did not detect a relationship between COX-2 protein levels and apoptotic response

\section{REFERENCES}

Alberts DS, Hixson L, Ahnen D, Bogert C, Einspahr J, Paranka N, Brendel K, Gross PH, Pamukcu R, Burt RW (1995) Do NSAIDs exert their colon cancer chemoprevention activities through the inhibition of mucosal prostaglandin synthetase? J Cell Biochem Suppl 22: 18-23

Anti M, Armuzzi A, Morini S, Iascone E, Pignataro G, Coco C, Lorenzetti R, Paolucci M, Covino M, Gasbarrini A, Vecchio F, Gasbarrini G (2001) Severe imbalance of cell proliferation and apoptosis in the left colon and in the rectosigmoid tract in subjects with a history of large adenomas. Gut 48: $238-246$

Arango HA, Icely S, Roberts WS, Cavanagh D, Becker JL (2001) Aspirin effects on endometrial cancer cell growth. Obstet Gynecol 97: 423-427 to aspirin in any cell type. Furthermore, the fact that we observed considerable variation in COX-2 expression within the CRC cell lines, which were all susceptible to aspirin-induced apoptosis, presents persuasive evidence that COX-2-independent as well as COX-2-dependent mechanisms play a role in the anti-tumour effects of NSAIDs (Rigas and Shiff, 2000).

Aspirin concentrations used here are relevant to pharmacological levels in clinical practice (1-3 mM) (Insel, 1996). Nonetheless, comparisons between cell culture concentrations and plasma levels are somewhat artificial, because of the inability to accurately mimic in vivo metabolism and tissue concentration of the agent in epithelial or tumour cells. Decreased basal levels of apoptosis and hyperproliferative mucosa have been observed in patients with adenomas, suggesting the existence of a 'field defect' in the colonic mucosa (Anti et al, 2001). Although we observed proportionally less apoptosis at lower concentrations of aspirin, there is evidence that low levels of apoptosis translate into significant tumour regression over time in cell kinetics studies (Pritchard and Watson, 1996). It remains to be determined whether aspirin redresses the balance by inducing apoptosis de novo in newly transformed colorectal epithelial cells destined to become malignant clones. There is evidence of $\mathrm{NF} \kappa \mathrm{B}$ involvement in colonic crypt differentiation and cell turnover in mouse colon, where $\mathrm{NF} \kappa \mathrm{B}$ activity is greater in proliferating cells at the base of crypts compared to mature cells at the surface (Inan et al, 2000). Thus, it is also possible that the drug corrects deranged mechanisms that permit escape from normal cellular turnover and apoptosis.

In summary, the data presented here demonstrate that there are substantial differences in the anti-tumour effects of aspirin and modulation of $\mathrm{NF} \kappa \mathrm{B}$ signalling between cancer cells of different tissue origin. The effect of aspirin on $\mathrm{NF} \kappa \mathrm{B}$ signalling and apoptosis does not appear to be related to expression levels of COX-2 or mutation status of APC, $\beta$-catenin, p53 and DNA MMR genes. This is important when considering translating these findings to clinical studies aimed at defining the $\mathrm{NF} \kappa \mathrm{B}$ response to aspirin in human colonic epithelium and tumours. The molecular basis of NSAID anti-tumour activity is complex, and our findings provide further evidence that the effects of aspirin on $\mathrm{NF} \kappa \mathrm{B}$ signalling have particular relevance to $\mathrm{CRC}$ chemoprevention.

\section{ACKNOWLEDGEMENTS}

We would like to thank Professor R Hay (University of St Andrews) for the gift of the $\mathrm{I} \kappa \mathrm{B} \alpha$ antibody and Professor R Brown for the A2780 cell line. The work was supported by a grant from the Scottish Office Health Department, Chief Scientist's Office (K/ MRS/50/C2719 and CZB/4/41) to MGD and LAS, and by a grant from Miss Urquhart's Charitable Trust to FVND. LAS is a Caledonian Research Fellow.
Boolbol SK, Dannenberg AJ, Chadburn A, Martucci C, Guo XJ, Ramonetti JT, Abreu-Goris M, Newmark HL, Lipkin ML, DeCosse JJ, Bertagnolli MM (1996) Cyclooxygenase-2 overexpression and tumor formation are blocked by sulindac in a murine model of familial adenomatous polyposis. Cancer Res 56: $2556-2560$

Bours V, Dejardin E, Goujon-Letawe F, Merville MP, Castronovo V (1994) The NF-kappa B transcription factor and cancer: high expression of NFkappa B- and I kappa B-related proteins in tumor cell lines. Biochem Pharmacol 47: $145-149$

Castano E, Dalmau M, Barragan M, Pueyo G, Bartrons R, Gil J (1999) Aspirin induces cell death and caspase-dependent phosphatidylserine 
externalization in HT-29 human colon adenocarcinoma cells (in process citation). Br J Cancer 81: 294-299

Charalambous MP, Maihofner C, Bhambra U, Lightfoot T, Gooderham NJ (2003) Upregulation of cyclooxygenase-2 is accompanied by increased expression of nuclear factor-kappa B and I kappa B kinase-alpha in human colorectal cancer epithelial cells. Br J Cancer 88: 1598-1604

Collet JP, Sharpe C, Belzile E, Boivin JF, Hanley J, Abenhaim L (1999) Colorectal cancer prevention by non-steroidal anti-inflammatory drugs: effects of dosage and timing (in process citation). Br J Cancer 81: 62-68

Cramer DW, Harlow BL, Titus-Ernstoff L, Bohlke K, Welch WR, Greenberg ER (1998) Over-the-counter analgesics and risk of ovarian cancer. Lancet 351: $104-107$

Dejardin E, Deregowski V, Chapelier M, Jacobs N, Gielen J, Merville MP, Bours V (1999) Regulation of NF-kappaB activity by I kappaB-related proteins in adenocarcinoma cells. Oncogene 18: 2567-2577

Eberhart CE, Coffey RJ, Radhika A, Giardiello FM, Ferrenbach S, DuBois RN (1994) Up-regulation of cyclooxygenase 2 gene expression in human colorectal adenomas and adenocarcinomas. Gastroenterology 107: $1183-1188$

Elder DJ, Halton DE, Hague A, Paraskeva C (1997) Induction of apoptotic cell death in human colorectal carcinoma cell lines by a cyclooxygenase- 2 (COX-2)-selective nonsteroidal anti-inflammatory drug: independence from COX-2 protein expression. Clin Cancer Res 3: 1679-1683

Fairfield KM, Hunter DJ, Fuchs CS, Colditz GA, Hankinson SE (2002) Aspirin, other NSAIDs, and ovarian cancer risk (United States). Cancer Causes Control 13: 535-542

Han EK, Arber N, Yamamoto H, Lim JT, Delohery T, Pamukcu R, Piazza GA, Xing WQ, Weinstein IB (1998) Effects of sulindac and its metabolites on growth and apoptosis in human mammary epithelial and breast carcinoma cell lines. Breast Cancer Res Treat 48: 195-203

Hanif R, Pittas A, Feng Y, Koutsos MI, Qiao L, Staiano-Coico L, Shiff SI, Rigas B (1996) Effects of nonsteroidal anti-inflammatory drugs on proliferation and on induction of apoptosis in colon cancer cells by a prostaglandin-independent pathway. Biochem Pharmacol 52: 237-245

Hardwick JC, van den Brink GR, Offerhaus GJ, van Deventer SJ, Peppelenbosch MP (2001) NF-kappaB, p38 MAPK and JNK are highly expressed and active in the stroma of human colonic adenomatous polyps. Oncogene 20: $819-827$

Howe LR, Subbaramaiah K, Brown AM, Dannenberg AJ (2001) Cyclooxygenase-2: a target for the prevention and treatment of breast cancer. Endocr Relat Cancer 8: $97-114$

Inan MS, Tolmacheva V, Wang QS, Rosenberg DW, Giardina C (2000) Transcription factor NF-kappaB participates in regulation of epithelial cell turnover in the colon. Am J Physiol Gastrointest Liver Physiol 279: G1282 - G1291

Insel P (1996) Analgesic-antipyretic and anti-inflammatory agents and drugs employed in the treatment of gout. In The Pharmacological Basis of Therapeutics, Hardman JG, Limberd LE, Molinoff PB, Rudden RW, Gilman AG (eds) pp 617-659. New York: McGraw-Hill

Kashfi K, Ryann Y, Qiao LL, Williams JL, Chen J, Del Soldato P, Traganos F, Rigas B (2002) Nitric oxide-donating nonsteroidal anti-inflammatory drugs inhibit the growth of various cultured human cancer cells: evidence of a tissue type-independent effect. J Pharmacol Exp Ther 303: $1273-1282$

Khuder SA, Mutgi AB (2001) Breast cancer and NSAID use: a meta-analysis. Br J Cancer 84: 1188 - 1192

Langman MJ, Cheng KK, Gilman EA, Lancashire RJ (2000) Effect of antiinflammatory drugs on overall risk of common cancer: case-control study in general practice research database. BMJ 320: $1642-1646$
Lind DS, Hochwald SN, Malaty J, Rekkas S, Hebig P, Mishra G, Moldawer LL, Copeland III EM, Mackay S (2001) Nuclear factor-kappa B is upregulated in colorectal cancer. Surgery 130: 363 - 369

Meier CR, Schmitz S, Jick H (2002) Association between acetaminophen or nonsteroidal antiinflammatory drugs and risk of developing ovarian, breast, or colon cancer. Pharmacotherapy 22: 303-309

Mooney LM, Al Sakkaf KA, Brown BL, Dobson PR (2002) Apoptotic mechanisms in T47D and MCF-7 human breast cancer cells. Br J Cancer 87: $909-917$

Noguchi M, Earashi M, Minami M, Miyazaki I, Tanaka M, Sasaki T (1995) Effects of piroxicam and esculetin on the MDA-MB-231 human breast cancer cell line. Prostagland Leukotr Essent Fatty Acids 53: 325-329

Pachman LM, Olufs R, Procknal JA, Levy G (1979) Pharmacokinetic monitoring of salicylate therapy in children with juvenile rheumatoid arthritis. Arthritis Rheum 22: 826-831

Pahl HL (1999) Activators and target genes of Rel/NF-kappaB transcription factors. Oncogene 18: 6853 - 6866

Parkin DM, Pisani P, Ferlay J (1999) Estimates of the worldwide incidence of 25 major cancers in 1990. Int J Cancer 80: 827-841

Piazza GA, Rahm AK, Finn TS, Fryer BH, Li H, Stoumen AL, Pamukcu R, Ahnen DJ (1997) Apoptosis primarily accounts for the growth-inhibitory properties of sulindac metabolites and involves a mechanism that is independent of cyclooxygenase inhibition, cell cycle arrest, and p53 induction. Cancer Res 57: $2452-2459$

Planchon P, Veber N, Magnien V, Prevost G, Starzec AB, Israel L (1995) Evidence for separate mechanisms of antiproliferative action of indomethacin and prostaglandin on MCF-7 breast cancer cells. Life Sci 57: $1233-1240$

Pritchard DM, Watson AJ (1996) Apoptosis and gastrointestinal pharmacology. Pharmacol Ther 72: 149-169

Qiao L, Hanif R, Sphicas E, Shiff SJ, Rigas B (1998) Effect of aspirin on induction of apoptosis in HT-29 human colon adenocarcinoma cells. Biochem Pharmacol 55: 53-64

Rayet B, Gelinas C (1999) Aberrant rel/nfkb genes and activity in human cancer. Oncogene 18: 6938-6947

Rigas B, Shiff SJ (2000) Is inhibition of cyclooxygenase required for the chemopreventive effect of NSAIDs in colon cancer? A model reconciling the current contradiction. Med Hypotheses 54: 210-215

Rosenberg L, Palmer JR, Rao RS, Coogan PF, Strom BL, Zauber AG, Stolley PD, Shapiro S (2000) A case - control study of analgesic use and ovarian cancer. Cancer Epidemiol Biomarkers Prev 9: 933 -937

Schreinemachers DM, Everson RB (1994) Aspirin use and lung, colon, and breast cancer incidence in a prospective study. Epidemiology 5: 138-146

Sotiriou C, Lacroix M, Lagneaux L, Berchem G, Body JJ (1999) The aspirin metabolite salicylate inhibits breast cancer cells growth and their synthesis of the osteolytic cytokines interleukins-6 and -11. Anticancer Res 19: $2997-3006$

Stark LA, Din FV, Zwacka RM, Dunlop MG (2001) Aspirin-induced activation of the NF-kappaB signaling pathway: a novel mechanism for aspirin-mediated apoptosis in colon cancer cells. FASEB J 15: $1273-1275$

Tang F, Tang G, Xiang J, Dai Q, Rosner MR, Lin A (2002) The absence of NF-kappaB-mediated inhibition of c-Jun N-terminal kinase activation contributes to tumor necrosis factor alpha-induced apoptosis. Mol Cell Biol 22: $8571-8579$

Thun MJ, Namboodiri MM, Calle EE, Flanders WD, Heath CWJ (1993) Aspirin use and risk of fatal cancer (see comments). Cancer Res 53: $1322-1327$

Vane JR (1971) Inhibition of prostaglandin synthesis as a mechanism of action for aspirin-like drugs. Nat New Biol 231: $232-235$ 